\title{
LITERASI KEUANGAN BAGI PENGURUS KOPERASI AMBOY BANTUL
}

\author{
Lita Yulita Fitriyani \\ 1UPN "Veteran" Yogyakarta \\ 1 lita.yulita@upnyk.ac.id
}

\begin{abstract}
This activity was conducted at amboy bantul cooperative consisting of producers and sellers of various processed foods, especially foods made from bananas. The type of business conducted by this cooperative is a business to save loans. This cooperative is a MicroFinance Institution (LKM)

Based on the observations, some of amboy bantul cooperative managers are not yet understanding financial literacy. Literacy is an individual's ability and skills in reading, writing, calculating, solving problems, processing data, conveying information and understanding information related to daily life. Initially, the board of AMBOY Bantul Cooperative did not yet understand the meaning of depreciation or depreciation of fixed assets that should be presented in the financial statements.

Therefore, this activity is intended to improve the ability of $A M B O Y$ Bantul cooperative management in understanding how to prepare the correct financial statements, especially in recognizing the burden of depreciation and accumulated depreciation of fixed assets by providing counseling and training. After the management of this cooperative participated in counseling and training, finally $A M B O Y$ Bantul cooperative managers can understand how to calculate the burden of depreciation, accumulated depreciation and presentation in financial statement.

They understand that depreciation expense accounts (all cooperative fixed assets) are presented on the Remaining Business Results Report as a reduction in service income accounts. They also understand that accumulated depreciation accounts reduce the acquisition price of each fixed asset presented on the balance sheet. Some administrators of AMBOY Bantul Cooperative can finally compile cooperative financial statements in accordance with Financial Accounting Standards for Entities Without Public Accountability (ETAP)
\end{abstract}

Keywords: literacy, finance, counseling, training

\begin{abstract}
Abstrak
Kegiatan ini dilakukan pada Koperasi AMBOY Bantul yang beranggotakan para produsen dan penjual aneka olahan makanan khususnya makanan
\end{abstract}


yang berbahan dasar pisang. Jenis usaha yang dilakukan oleh koperasi ini adalah usaha simpan pinjam. Koperasi ini merupakan Lembaga Keuangan Mikro (LKM)

Berdasarkan hasil pengamatan, beberapa pengurus koperasi AMBOY Bantul banyak yang belum memahami literasi keuangan. Literasi adalah kemampuan dan keterampilan individu dalam membaca, menulis, menghitung, memecahkan masalah, mengolah data, menyampaikan informasi dan memahami informasi yang berhubungan dengan kehidupan sehari-hari. Awalnya, pengurus Koperasi AMBOY Bantul belum memahami makna depresiasi atau penyusutan aset tetap yang harus disajikan dalam laporan keuangan. Oleh karena itu, kegiatan ini ditujukan untuk meningkatkan kemampuan pengurus koperasi AMBOY Bantul dalam memahami cara menyusun laporan keuangan yang benar khususnya dalam mengakui beban depresiasi dan akumulasi depresiasi aset tetap dengan cara memberikan penyuluhan dan pelatihan. Setelah para pengurus koperasi ini mengikuti penyuluhan dan pelatihan, akhirnya pengurus koperasi AMBOY Bantul dapat memahami cara menghitung beban depresiasi, akumulasi depresiasi dan penyajiannya di dalam laporan keuangan. Mereka memahami bahwa akun beban depresiasi (semua aset tetap koperasi) disajikan pada Laporan Sisa Hasil Usaha sebagai pengurang akun pendapatan jasa. Mereka pun memahami bahwa akun akumulasi depresiasi mengurangi harga perolehan setiap aset tetap yang disajikan dalam neraca. Beberapa pengurus Koperasi AMBOY Bantul akhirnya dapat menyusun laporan keuangan koperasi yang sesuai dengan Standar Akuntansi Keuangan untuk Entitas Tanpa Akuntabilitas Publik (ETAP)

Kata Kunci: literasi, keuangan, penyuluhan, pelatihan

\section{PENDAHULUAN}

Menurut Batubara (2012) koperasi adalah wadah untuk bergabung dan berusaha bersama, agar kekurangankekurangan yang berhubungan dengan kegiatan ekonomi oleh seseorang dapat diatasi, setidak-tidaknya diperkecil. Oleh karena itu, koperasi merupakan media untuk dapat menolong diri sendiri, sehingga mampu berusaha memenuhi kebutuhan dan memperbaiki penghidupannya. Koperasi sebagai alat perjuangan ekonomi terkandung dalam azas-azas dan sendi-sendinya yang bermakna bahwa tujuan koperasi itu bukan untuk mengejar keuntungan semata-mata, tetapi yang utama ialah memberikan jasa- jasa agar para anggotanya bersemangat dan bergairah kerja, sehingga tercapai peningkatan pendapatannya. Koperasi juga memberikan bimbingan dan usaha pembinaan kepada para anggotanya (yang umumnya berekonomi lemah) agar mereka masing-masing dapat memperbaiki cara kerja, mutu hasil kerja dan jumlah hasil kerja, sehingga dalam wadah koperasi secara terpadu dan 
terarah mereka dapat memberikan sumbangan besar, baik terhadap pembangunan masyarakat pedesaan, regional dan nasional.

Berdasarkan data Dinas Perindustrian Perdagangan Koperasi dan Pertanian (Disperindagkoptan) Kota Yogyakarta memiliki 554 koperasi. Namun dari jumlah tersebut, 98 koperasi pasif. Salah satu Koperasi yang masih aktif di Yogyakarta yaitu Koperasi "AMBOY" (Agro Mirasa Boga Bantul Yogyakarta) di Desa Sidomulyo, Kecamatan Bambanglipuro, Kabupaten Bantul, Yogyakarta. Koperasi ini merupakan usaha dibidang olahan makanan hasil pertanian non gandum. Pengolahan minuman dan makanan adalah produk yang banyak diminati dan memiliki daya serap pasar cukup tinggi. Hal tersebut menyebabkan adanya koperasi yang bergerak di bidang pengolahan makanan yang dapat menambah profit bagi masyarakat. Koperasi "AMBOY" dibentuk oleh 10 lembaga petani, forum bisnis petani, gapoktan dan Forum Organisasi Petani Bantul pada tanggal 19 April 2012 di BKP3 Kabupaten Bantul. Masyarakat Desa Sidomulyo mayoritas bekerja sebagai petani pisang. Menurut Profil Desa dan Kelurahan Desa Sidomulyo 2017 produktifitas tanaman pisang di
Desa Sidomulyo mencapai 250 ton pertahun. Dari jumlah tersebut masih banyak petani di Desa Sidomulyo yang menjual dalam bentuk mentah. Penghasilan yang didapat dari tanaman pisang sangat sedikit bahkan belum dapat memenuhi kebutuhan hidup. Untuk menambah perekonomian keluarga, petani pisang di Desa tersebut memilih bergabung dengan Koperasi "AMBOY". Dengan bergabung di koperasi tersebut petani bisa belajar mengolah pisang menjadi berbagai macam olahan makanan yang dapat menambah nilai jual pisang, seperti dibuat menjadi sale pisang, kripik pisang, roti pisang dan lain sebagainya (Septianingsih, 2020).

Untuk membantu para anggota koperasi dalam memenuhi modal usaha maka koperasi ini bergerak di bidang jasa simpan pinjam. Para anggota koperasi wajib menyetorkan sejumlah dana sebagai simpanan pokok dan simpanan wajib serta menyetorkan dana tambahan sebagai simpanan suka rela. Simpanan pokok adalah sejumlah dana yang wajib dibayarkan oleh setiap anggota kepada koperasi pada saat masuk menjadi anggota koperasi. Simpanan wajib adalah jumlah simpanan tertentu yang harus dibayarkan oleh anggota kepada koperasi dalam waktu dan kesempatan tertentu, misalnya tiap bulan dengan jumlah 
simpanan yang sama untuk setiap bulannya. Simpanan pokok dan simpanan wajib tidak dapat diambil kembali selama yang bersangkutan masih menjadi anggota koperasi. Simpanan sukarela adalah simpanan yang besarnya tidak ditentukan namun tergantung pada kemampuan anggota. Simpanan sukarela dapat disetorkan dan diambil setiap saat oleh anggota tersebut. Anggota Koperasi AMBOY yang membutuhkan dana dapat mengajukan kredit atau pinjaman pada koperasi ini dan debitur wajib mengembalikan dana tersebut dengan cara diangsur termasuk menyetor dana jasa pinjaman.

Modal yang diterima Koperasi AMBOY tidak hanya berasal dari anggota koperasi saja, ada pula pihak ketiga yang ikut memberikan bantuan pada koperasi ini. Pihak ketiga ini memberikan bantuan dalam bentuk pengadaan beberapa alat produksi seperti mixer, blender, panci dan lain-lain. Semua barang tersebut diakui oleh koperasi ini sebagai aset tetap dan selalu muncul dalam laporan keuangannya, yaitu pada neraca. Ternyata barang-barang yang diterima beberapa tahun tersebut, tidak dapat dimanfaatkan oleh anggota koperasi dalam mendukung kegiatan produksinya karena spesifikasi yang diberikan tidak sesuai dengan spesifikasi yang dibutuhkan para anggota.
Pada tahun 2021 sudah tidak ada barang yang dapat digunakan lagi karena sudah rusak parah namun masih tetap disimpan dalam gudang dengan alasan khawatir suatu saat nanti pihak ketiga (pemberi hibah) tersebut meminta pengurus koperasi AMBOY Bantul untuk menunjukkan keberadaan barang-barang hibah tersebut. Oleh pengurus koperasi, semua nama barang hibah tersebut disajikan dalam neraca dan nilai nominalnya disesuaikan dengan harga perolehan setiap jenis barang tersebut. Pengurus koperasi tidak mencatat adanya beban depresiasi dan akumulasi depresiasi atas setiap aset tersebut. Untuk aset tetap yang ada dan digunakan oleh pengurus koperasi seperti meja, kursi, LCD dan proyektor malah belum dicatat dan disajikan pada neraca. Di sini tampak bahwa pengurus koperasi AMBOY masih belum paham cara menyajikan aset tetap dalam laporan keuangan, artinya literasi keuangan pengurus Koperasi AMBOY masih relatif rendah.

Menurut Kamus Besar Bahasa Indonesia, literasi adalah kesanggupan membaca dan menulis. Literasi dapat diartikan pula sebagai kemampuan dan keterampilan individu dalam membaca, menulis, menghitung, memecahkan masalah, mengolah data, menyampaikan informasi dan memahami informasi yang 
berhubungan dengan kehidupan seharihari. Jika dihubungkan dengan keuangan maka literasi keuangan berarti kecakapan atau memahami hal-hal yang berhubungan dengan keuangan baik menghitung, mencatat, menyajikan maupun menganalisis.

Berdasarkan masalah tersebut, dilakukanlah penyuluhan dan pelatihan kepada pengurus Koperasi AMBOY mengenai pengertian depresiasi atau penyusutan aset tetap, menjelaskan cara menghitung dan mencatat beban depresiasi, menjelaskan cara menghitung dan mencatat akumulasi depresiasi aset tetap serta menyajikannya dalam laporan keuangan. Pengurus Koperasi AMBOY diberi simulasi kasus sebagai sarana latihan menyusun laporan keuangan yang sesuai dengan standar laporan keuangan koperasi berdasarkan Standar Akuntansi Keuangan untuk Entitas Tanpa Akuntabilitas Publik (SAK-ETAP), Nomor 12/Per/M.KUKM/IX/2015.

\section{METODE DAN PELAKSANAAN}

Berdasarkan masalah yang muncul yaitu pengurus Koperasi AMBOY Bantul belum memahami makna dan cara menghitung depresiasi aset tetap maka tim pengabdian pada masyarakat melakukan metode training/pelatihan untuk mengatasi masalah yang dihadapi Koperasi AMBOY Bantul.

\section{Metode}

Metode kegiatan yang dilakukan adalah training atau pelatihan mengenai penyusunan laporan keuangan untuk koperasi dan memberikan penyuluhan untuk meningkatkan pemahaman mengenai pengelolaan keuangan koperasi AMBOY. Adapun materi yang disampaikan adalah pengertian aset tetap, depresiasi atau penyusutan aktiva tetap, cara menghitung depresiasi tahunan dan cara menghitung serta menyajikan akumulasi depresiasi pada laporan keuangan. Depresiasi adalah harga perolehan aset tetap yang dialokasikan secara rasional dan sistematis menjadi beban di setiap periode akuntansi sampai masa manfaat aset tetap tersebut habis atau sampai aset tetap tersebut sudah tidak dimanfaatkan lagi (Jusup, 2011). Ketika depresiasi aset tetap diakui maka tidak ada uang atau dana yang dikeluarkan. Hal ini sesuai dengan jurnal untuk mencatat depresiasi yaitu beban depresiasi dicatat di sisi debit dan akumulasi depresiasi dicatat di sisi kredit dengan jumlah nominal yang sama. Jadi sisi kreditnya bukan akun kas melainkan akumulasi depresiasi. Menurut Weygandt et. all (2015), metode untuk menghitung depresiasi ada tiga yaitu metode garis 
lurus (straight line method), metode berdasarkan unit yang dihasilkan atau aktivitas yang dilakukan (unit of activity method) dan metode saldo menurun (declining balance method). Pada kesempatan ini, pengurus koperasi hanya diajarkan satu metode saja yaitu metode garis lurus karena metode ini adalah metode yang termudah dan sesuai pula untuk diterapkan pada koperasi. Rumus depresiasi dengan metode garis lurus adalah sebagai berikut :

Depresiasi per tahun

$=\frac{\text { harga perolehan }- \text { taksiran nilai residu }}{\text { taksiran umur ekonomis }}$

Harga perolehan (cost) adalah harga faktur bersih setelah dikurangi diskon pembelian jika ada lalu ditambah seluruh beban yang muncul sehubungan dengan perolehan aset tetap tersebut seperti beban angkut pembelian, beban perakitan dan beban uji coba sampai aset tetap tersebut siap digunakan. Taksiran nilai residu (residual value) adalah taksiran nilai tunai yang diharapkan dapat direalisasi ketika aset tetap tersebut sudah tidak digunakan lagi.

Taksiran umur ekonomis (useful life) adalah taksiran jangka waktu normal pemakaian aset tetap. Menurut Peraturan Menteri Keuangan No. 96/PMK.03/2009 tentang jenis-jenis harta yang termasuk dalam kelompok harta berwujud bukan bangunan untuk keperluan penyusutan ada 4 kelompok umur ekonomis aset tetap yaitu 4 tahun, 8 tahun, 16 tahun dan 20 tahun. Aset tetap yang ada di koperasi AMBOY adalah aset tetap dengan umur ekonomis 4 sampai 8 tahun seperti genset, mixer, blender, spinner, oven, timbangan, meja, kursi, LCD dan laptop.

Aset tetap tersebut dapat dihentikan pemakaiannya di akhir umur ekonomis (masa manfaat) ataupun sebelum umur ekonomisnya habis. Aset tetap yang dihentikan sebelum umur ekonomis habis dapat disebabkan karena ditukar dengan aset tetap lain baik sejenis maupun tidak sejenis atau karena aset tetap tersebut rusak parah, dihibahkan atau dijual.

Nilai aset tetap harus disajikan pada neraca sebesar nilai buku (book value). Nilai buku dihitung dari harga perolehan yang dikurangi oleh akumulasi depresiasi (Weygandt et all, 2015).

Dalam training ini, pengurus koperasi dilatih menghitung depresiasi tahunan atas aset tetap yang dimiliki koperasi AMBOY dan dilatih cara menyajikannya dalam laporan keuangan dimana akumulasi depresiasi harus muncul pada neraca dan mengurangi harga perolehan aset tetap. Beban depresiasi harus muncul pada Laporan Sisa Hasil Usaha dan mengurangi penghasilan jasa koperasi AMBOY. Selisih antara penghasilan jasa dengan total beban koperasi adalah Sisa 
Hasil Usaha (SHU). Selama ini Koperasi AMBOY Bantul hanya menyajikan beban operasional Rapat Anggota Tahunan (RAT) saja pada Laporan SHU tanpa menyajikan adanya beban depresiasi aktiva tetap.

\section{Pelaksanaan Kegiatan}

Kegiatan penyuluhan dan pelatihan menyusun laporan keuangan diikuti oleh enam orang pengurus Koperasi AMBOY, tampak pada beberapa foto berikut ini:
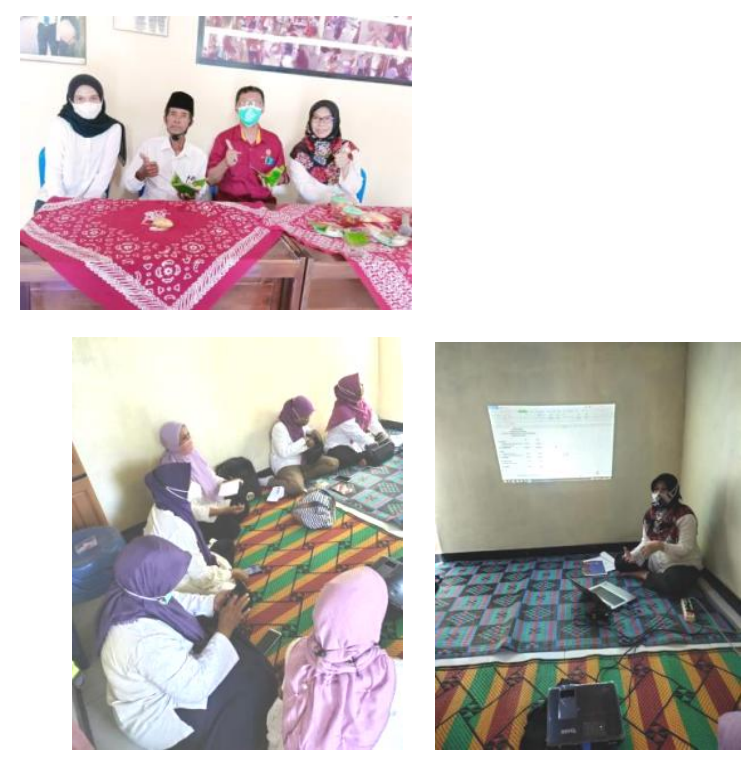

Gambar 1. Pelatihan Menyusun Laporan Keuangan

\section{HASIL DAN PEMBAHASAN}

Dalam kegiatan ini seluruh peserta sangat berantusias ingin mengetahui cara tepat mengelola keuangan Koperasi AMBOY termasuk dalam menyusun laporan keuangan yang sesuai dengan standar yang berlaku. Para peserta belajar menghitung depresiasi tahunan berdasarkan contoh yang disampaikan oleh instruktur (tim abdimas).

Misal diketahui pada tanggal 10 April 2019, koperasi AMBOY membeli laptop senilai Rp 4.250.000, taksiran nilai residu sebesar Rp 250.000 dan taksiran umur ekonomisnya 4 tahun maka beban depresiasi tahun 2019 adalah :

((4.250.000 - 250.000) / 4 tahun) x 9/12 $=\mathrm{Rp} 750.000$

Beban depresiasi laptop untuk tahun 2020 , 2021 dan 2022 adalah :

((4.250.000 - 250.000) / 4 tahun) x 12/12 $=$ Rp 1.000.00o per tahun

Beban depresiasi laptop untuk tahun 2023 adalah :

((4.250.000 - 250.000) / 4 tahun $) \times 3 / 12$ $=\operatorname{Rp} 250.000$

Ringkasan perhitungan Beban Depresiasi, Akumulasi Depresiasi Laptop dan Nilai Buku Laptop per tahun tampak pada tabel di bawah ini.

Tabel 1. Depresiasi Laptop Per Tahun

\begin{tabular}{|c|r|r|r|}
\hline \multicolumn{1}{|c|}{ Tanggal } & $\begin{array}{c}\text { Beban } \\
\text { Depresiasi }\end{array}$ & $\begin{array}{c}\text { Akumulasi } \\
\text { Depresiasi }\end{array}$ & Nilai Buku \\
\hline $10 / 4 / 2019$ & & & 4.250 .000 \\
\hline $31 / 12 / 2019$ & 750.000 & 750.000 & 3.500 .000 \\
\hline $31 / 12 / 2020$ & 1.000 .000 & 1.750 .000 & 2.500 .000 \\
\hline $31 / 12 / 2021$ & 1.000 .000 & 2.750 .000 & 1.500 .000 \\
\hline $31 / 12 / 2022$ & 1.000 .000 & 3.750 .000 & 500.000 \\
\hline $11 / 4 / 2023$ & 250.000 & 4.000 .000 & 250.000 \\
\hline TOTAL & 4.000 .000 & & \\
\hline
\end{tabular}


Aset tetap yang disajikan pada neraca per

31 Desember 2019 adalah sebagai berikut:

Laptop

Rp 4.250.000

Akumulasi depresiasi laptop (750.000)

Nilai buku laptop

Rp 3.500.000

Aset tetap yang disajikan pada neraca per

31 Desember 2020 adalah sebagai berikut:

Laptop

$\operatorname{Rp} 4.250 .000$

Akumulasi depresiasi laptop (1.750.000)

Nilai buku laptop

Rp 2.500.000

Aset tetap yang disajikan pada neraca per

31 Desember 2023 adalah sebagai berikut:

Laptop

$\operatorname{Rp} 4.250 .000$

Akumulasi

depresiasi

laptop

(4.000.000)

Nilai buku laptop

Rp $\quad 250.000$

Jika akun aset tetap ada 5 maka akun akumulasi depresiasinya juga ada 5 sedangkan untuk akun beban depresiasi hanya dicatat 1 akun saja dengan jumlah nominal sebesar beban depresiasi semua aset tetap pada tahun tersebut. Misal, pada tahun 2021 ada beban depresiasi laptop sebesar Rp 1.000.000, beban depresiasi blender sebesar Rp 100.000 dan beban depresiasi oven sebesar Rp 200.000 maka pada Laporan Sisa Hasil Usaha 2021 dicatat beban depresiasi sebesar Rp 1.300.000

Di akhir umur ekonomis (tahun 2023) tampak bahwa nilai buku (book value) laptop tersebut sebesar Rp 250.000. Hal ini menunjukkan bahwa secara akuntansi, sejak 10 April 2023 laptop tersebut sudah tidak layak lagi untuk digunakan karena umur ekonomisnya sudah habis dan harus dihapus dari catatan neraca tahun 2024 jika Koperasi AMBOY tidak membeli laptop yang baru. Seandainya laptop ini dijual maka diharapkan dapat laku terjual minimal seharga Rp 250.000.

\section{PENUTUP}

Kegiatan ini terselenggara karena didukung oleh berbagai pihak. Untuk itu, dihaturkan terimakasih kepada LPPM UPN “Veteran” Yogyakarta yang telah memilih tim ini sebagai salah satu penerima hibah penelitian terapan internal. Tak lupa kami haturkan terimakasih pula pada seluruh pengurus serta anggota Koperasi AMBOY Bantul yang telah bersedia menjadi mitra tim kami pada program ini.

\section{Simpulan}

Setelah diberikan training /pelatihan menyusun laporan keuangan, sudah terjadi peningkatan pemahaman pengurus Koperasi AMBOY Bantul mengenai cara menyusun laporan keuangan yang tepat.

\section{Saran}

Agar literasi keuangan pengurus Koperasi AMBOY semakin baik maka: 
1. Sebaiknya pihak akademisi melakukan pendampingan secara terus menerus karena sebagian besar latar belakang pendidikan para pengurus Koperasi AMBOY Bantul adalah lulusan SMA yang kurang paham mengenai cara mencatat dan menyusun laporan keuangan yang sesuai dengan ETAP.

2. Sebaiknya DISPERINDAGKOP DIY secara rutin memantau perkembangan semua koperasi yang ada di Kabupaten Bantul termasuk memantau perkembangan Koperasi AMBOY.

3. Sebaiknya aset tetap yang dimiliki Koperasi AMBOY Bantul segera disajikan dalam neraca untuk dilaporkan dalam RAT yang akan datang

4. Sebaiknya anggota Koperasi AMBOY Bantul turut berpartisipasi belajar mengelola keuangan dan menyusun laporan keuangan sejak dini sebagai persiapan ketika terjadi pergantian kepengurusan koperasi.

\section{DAFTAR PUSTAKA}

Batubara, Mustopa M. 2021. Koperasi Pertanian. Penerbit: Universitas Muhammadiyah Palembang. ISBN 978-979-98015-7-9
Jusup, Al. H. 2011. Dasar-dasar Akuntansi. Jilid 2. Penerbitan : STIE YKPN Yogyakarta.

Peraturan Menteri Keuangan No. 96/PMK.03/2009 tentang jenisjenis harta yang termasuk dalam kelompok harta berwujud bukan bangunan untuk keperluan penyusutan.

Standar Akuntansi Keuangan untuk Entitas Tanpa Akuntabilitas Publik (SAK - ETAP), Nomor 12/Per/M.KUKM/IX/2015.

Septianingsih, Lia. 2020. Analisis Ekonomi Koperasi "AMBOY” (Agro Mirasa Boga Yogyakarta) Desa Sidomulyo, Kecamatan Bambanglipuro, Kabupaten Bantul, DIY. Skripsi Universitas Muhammadiyah Yogyakarta.

Weygandt, Jerry J.; Kimmel, Paul D.; and Kieso, Donald E. 2015. Financial Accounting IFRS. $3^{\text {rd }}$ edition. Wiley. ISBN-13 978-1-118-97808-5 